\title{
JUURNAL.RU
}

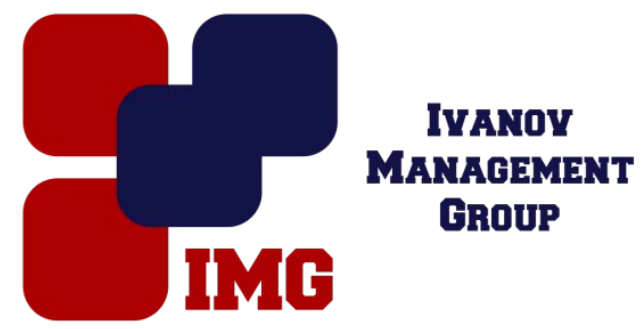

\author{
Шелуханов С.С. ${ }^{1}$, Шелуханова А.В. ${ }^{2}$ \\ ${ }^{1}$ Тамбовский государственный технический университет \\ ${ }^{2}$ Тамбовский государственный университет имени Г.Р. Державина \\ Тамбов, Россия
}

doi: 10.18411/lj-28-02-2017-2-04

idsp 000001:lj-28-02-2017-2-04

\section{Психологические особенности дознания несовершеннолетних}

\section{Аннотация}

Статья анализирует психологические особенности дознания несовершеннолетних, производится анализ личности подростка, совершившего преступление. Также рассматриваются стадии дознания несовершеннолетних преступников.

Ключевые слова: дознание несовершеннолетних, личность несовершеннолетнего правонарушителя, основные этапы допроса.

Знание психологических особенностей подростков способствует правильному решению задач расследования преступлений и перевоспитания несовершеннолетних преступников. Работники правоохранительных органов и в первую очередь органов дознания, используя эти знания, обеспечивают правильную диагностику личности несовершеннолетнего, индивидуальный подход к нему, выбор и применение наиболее соответствующих ситуации тактических приемов и др.

Наиболее удачный анализ личности несовершеннолетнего правонарушителя на предварительном следствии соответствует следующей схеме:

1. наследственно-биологические факторы,

2. ближайшее социальное окружение подростка,

3. личностные характеристики подростка,

4. правосознание подростка.

К кризисным явлениям, характеризующим психофизиологическое развитие подросткового возраста, которые могут представлять определенные предпосылки трудновоспитуемости и асоциального поведения, можно отнести следующие особенности организма и психики подростка:

1. Ускоренное и неравномерное развитие организма подростка в период полового созревания, 
2. Изменения в характере взаимоотношений со взрослыми, выражающиеся в повышенной конфликтности подростка с родителями,

3. Изменения в характере взаимоотношений со сверстниками, как с представителями своего, так и противоположного пола.

Известно, что в подростковом возрасте отмечаются снижение порога возбудимости центральной нервной системы, ослабление в ней процессов торможения и преобладание процессов возбуждения, неадекватность и дезинтегрированность реакций организма подростка на воздействие различных внешних факторов, возникновение повышенного интереса к событиям жизни, стремление к личному участию в них, переоценка своих сил, прав и возможностей. Все это имеет место на фоне повышенной эмоциональности и эффективности.

Естественно, что без участия психолога следователь и суд не в состоянии определить, насколько сказались те или иные возрастные особенности на имеющей уголовно-правовое значение деятельности несовершеннолетнего или подростка.

При анализе причин антиобщественной ориентации личности подростка психолог исследует особенности формирования его правосознания, реальных жизненных ценностей, нравственно-нормативных установок и соотносит их с выделенными индивидуально-типологическими и характерологическими особенностями. При исследовании специфики принятия решений изучаются индивидуальные свойства личности.

При допросе несовершеннолетних наряду с общими закономерностями, характерными для этого следственного действия, следует учитывать ряд особенностей, которые прежде всего связаны с возрастом несовершеннолетних.

Каждый допрос несовершеннолетних можно разделить на следующие 5 этапов.

1. На первоначальном этапе допроса следователь, как правило, в устной форме получает от несовершеннолетнего допрашиваемого его анкетные данные. На этом этапе оба собеседника приблизительно намечают линию своего дальнейшего поведения по отношению друг к другу. Главная задача следователя - правильно диагностировать личность допрашиваемого.

2. Период вступления в психологический контакт между допрашиваемым и допрашивающим - сущность второго этапа допроса. Следует отметить, что контакт устанавливается не на каждом допросе, однако практически каждый следователь пытается его достигнуть. На этой стадии темой беседы являются обычные незначительные для существа дела вопросы; как правило, они касаются биографии допрашиваемого, его учебы, увлечения и т.д. 
3. Главная часть допроса. В этот период следователь стремится получить от допрашиваемого основную информацию по делу. При правильно организованном допросе это обычно удается.

4. Затем следователь сопоставляет полученную на допросе с уже имеющейся у него по делу информацией и пытается устранить противоречия, неясность, неточности и т.д.

5. На заключительном этапе допроса следователь различными способами (рукопись, машинопись, магнитофонная запись, стенограмма) заносит в протокол полученную в результате допроса информацию и представляет эту информацию уже в письменном виде допрашиваемому, который, подтвердив правильность записанного в протокол, его подписывает. На этой стадии важно сохранить лексические особенности речи несовершеннолетнего.

Анализ успешных допросов несовершеннолетних правонарушителей позволяет дать следующие практические рекомендации.

У «трудного» подростка надо в первую очередь выявлять положительные качества, на базе которых только и возможно достижение с ним психологического контакта и его перевоспитание.

Изучение недостатков «трудного» подростка чаще происходит опосредствованно (через других лиц в ходе конкретной деятельности, в естественной обстановке).

Понять такого подростка можно только в том случае, если тщательно изучить среду, людей, которые его воспитывали ранее, его товарищей по двору, улице, классу.

Надо всемерно побуждать воспитанника к самопознанию и самооценке: никакое точное знание психологии «трудных» подростков не даст результатов, если сам подросток не убедится в правильности данной ему оценки, не осознает нетерпимости своих недостатков.

Таким образом, особое внимание нужно обращать на возникающие самопроизвольно малые группы подростков (внутри классного коллектива, а также во дворах больших домов, около зрелищных предприятий, магазинов и др.). Общим для них (или по крайней мере для большинства) является наличие наиболее влиятельных для данной группы лиц. Задача состоит в том, чтобы привлечь в качестве своих союзников тех, кто положительно влияет на ребят, и нейтрализовать тех, кто оказывает отрицательное влияние. 


\section{Литература}

1. Конституция Российской Федерации (принята на всенародном голосовании 12 декабря 1993 г.)(с изм. от 21.07.2014г. N11-ФКЗ) [Электронный ресурс]: Гарант. Информационно-правовой портал. http://ivo.garant.ru/\#/document/10103000/entry/0:1

2. Уголовно-процессуальный кодекс Российской Федерации от 18 декабря 2001 г. N 174-Ф3 ( в ред. от 01.05.2016 г, с изм. и доп. от 01.05.2016 г. №139-Ф3) [Электронный ресурс]:Гарант. Информационно-правовой доступа:http://ivo.garant.ru/\#/document/12125178/paragraph/53424899:6

3. Арестова Е.Н. Производство органами дознания неотложных следственных действий по уголовным делам, по которым обязательно производство предварительного следствия // Российский следователь. 3/4 М.; Юрист, 2003. 3/4 № 10. 3/4 С.5-6.

4. Баяхчев В.Г. Недопустимые доказательства // Комментарий к Уголовно-процессуальному кодексу РК / Под общ. ред.В. В. Мозякова. 3/4 М., 2002. 3/4 425 с.

5. Беляков А.М. Служба судебных приставов: дознание по уголовным делам // Закон и право. 3/4 М.; ЮНИТИ-ДАНА, 2003. 3/4 № 12. 3/4С.26-28. 